\title{
ARTIKEL AUDIT SISTEM INFORMASI APLIKASI PERSEDIAAN PADA PT SS
}

\section{Erika Stacia Marsailis 155100026}

Universitas Mitra Indonesia, Sistem Informasi

Mahasiswa@umitra.ac.id

\begin{abstract}
ABSTRAK
tujuan penelitian adalah untuk mengevaluasi dan mengetahui sejauh mana sistem informasi aplikasi persediaan yang sedang berjalan (meliputi pengendalian manajemen dan pengendalian aplikasi) telah mampu memberikan informasi yang andal dan tempat waktu serta menekan resiko hingga pada tingkat yang dapat diterima oleh perusahaan juga memberikan rekomendasi-rekomendasi bagi perusahaan dalam rangka meminimalisasi resiko yang ada pada saat ini. Metode penelitian menggunakan "around the computer" adalah audit melalui pengujian dan pengevaluasian pengendalian manajemen, dalam menjalankan pengendalian input dan output hanya untuk sistem aplikasi persediaan berlandaskan mutu dari input dan output yang akan menghasilkan suatu laporan. Hasil dari penelitian ini adalah mengetahui aplikasi sistem informasi persediaan yang digunakan perusahaan SS telah memadai dan dapat memberikan informasi yang andal dan tepat waktu sehingga mempermudah Manajemen dalam mengambil suatu keputusan yang berkaitan dengan kebijakan persediaan.
\end{abstract}

Kata kunci: audit, sistem informasi persediaan, pengendalian, perusahaan 


\section{A. PEndahuluan}

Dengan semakin ketatnya persaingan bisnis di dalam dunia usaha, kecepatan dan ketepatan dalam bertindak merupakan suatu hal fundamental yang harus terintegrasi di seluruh departemen perusahaan. Tanpa didukung informasi yang akurat, relevan, dan cepat, maka kecepatan dan ketepatan dalam bertindak tidak akan pernah terealisasi. Untuk mewujudkan informasi yang ideal bagi perusahaan, diperlukan suatu penerapan teknologi informasi yang andal di dalam perusahaan. Peran penting teknologi informasi di seluruh lini perusahaan telah terbukti memberikan banyak manfaat yang signifikan dalam menunjang kualitas dan optimalisasi kinerja perusahaan.

PT SS merupakan salah satu perusahaan distributor yang juga menerapkan teknologi informasi pada sistem perusahaannya. Adapun aktivitas utama dari perusahaan ini adalah mendistribusikan alumunium dan gypsum ke perusahaan lain (suplier) di Indonesia yang bergerak di bidang tersebut. Sebagai perusahaan yang bergerak di bidang distribusi, sudah barang tentu pengelolaan inventori menjadi salah satu aspek vital yang perlu mendapatkan porsi khusus dalam pengelolaannya. Salah satu solusinya adalah dengan menerapkan teknologi informasi pada sistem persediaan agar informasi yang diperoleh lebih akurat dan cepat sehingga pengelolaan inventori pun menjadi lebih efektif dan efisien.

Oleh sebab itu, sistem persediaan menjadi sangat penting karena umumnya persediaan merupakan komponen aktiva lancar yang jumlahnya cukup material dan merupakan objek manipulasi serta tempat terjadinya kesalahan-kesalahan besar. Penentuan besarnya nilai persediaan secara langsung mempengaruhi biaya barang yang dijual (cost of good sales) sehingga berpengaruh pula terhadap perhitungan laba tahun yang bersangkutan. Seringkali persediaan disimpan di berbagai tempat sehingga menyulitkan pengawasan dan perhitungan fisiknya. Mengingat begitu luasnya aspek audit sistem informasi, maka penelitian khusus hanya membahas audit pada sistem informasi persediaan yang dimulai dari Pengendalian Manajemen (Management Control) dan Pengendalian Aplikasi (Application Control). Metode audit yang digunakan adalah metode Around the Computer.

Tujuan dari pelaksanaan audit sistem informasi persediaan ini adalah mengidentifikasi permasalahan yang terjadi pada sistem informasi persediaan, memastikan bahwa dokumen sumber yang di-input ke sistem aplikasi persediaan benar dan menghasilkan output yang akurat datanya, mengevaluasi kelemahan-kelemahan yang 
mungkin ditemukan di dalam sistem pengendalian internal, memberikan rekomendasi untuk memperbaiki kelemahan dan permasalahan yang terjadi pada sistem aplikasi persediaan pada PT SS, dalam rangka meminimalisasi resiko yang ada pada saat ini dan yang akan terjadi di kemudian hari.

\section{B. TINJAUAN PUSTAKA}

Definisi audit sistem informasi adalah "Information systems auditing is the process of collecting and evaluating evidence to determine whether a computer system safeguards assets, maintains data integrity, allows organizational goals to be achieved effectively, and uses resources efficiently" (Weber, 1999: 10,. Intinya, audit sistem informasi adalah proses pengumpulan dan pengevaluasian bukti untuk menentukan apakah sistem komputer dapat melindungi aset, memelihara integritas data, memungkinkan pencapaian tujuan organisasi secara efektif dan penggunaan sumber daya secara efisien.

Definisi sistem pengendalian internal menurut The Information System Control and Audit Association (ISACA), yang dikutip oleh Cangemi dan Singleton dalam bukunya, Managing the Audit Function (2003: 65) adalah "Internal control system is the policies, procedures, practices, and organizational structures, designed to provide reasonable assurance that business objectives will be achieved and that undesired events will be prevented, or detected and corrected."

Maksud dari pernyataan tersebut adalah bahwa sistem pengendalian internal merupakan kebijakan, prosedur, praktik-praktik, dan struktur organisasi yang didesain untuk memberikan jaminan yang layak pada upaya pencapaian tujuan bisnis yang akan dicapai dan memastikan kejadian-kejadian yang tidak diinginkan akan dicegah, atau dideteksi dan dikoreksi.

Berdasarkan definisi tersebut, pengendalian dikelompokkan menjadi 3 bagian, yaitu (1) Preventive Control merupakan instruksi (perintah) yang ditempatkan pada dokumen sumber untuk mencegah/menjaga terjadinya kesalahan dalam pengisiannya; (2) Detective Control merupakan pengendalian ini digunakan untuk menemukan/mengetahui bila terjadi kesalahan data yang diinput di dalam sistem; (3) Corrective Controls merupakan pengendalian ini digunakan untuk memperbaiki masalah yang ditemukan pada Detective Control. Pengendalian ini terdiri dari program yang menggunakan kode khusus yang dapat memperbaiki data yang rusak/error karena kesalahan pada komunikasi on line. 
Berdasarkan bidang yang diaudit, jenis-jenis audit terdiri dari 6 audit, yaitu (1) Audit Keuangan (Financial Audit), untuk menentukan apakah laporan keuangan secara keseluruhan telah dinyatakan sesuai dengan kriteria tertentu; (2) Audit Operasional (Operational Audit), bertujuan untuk pemeriksaan efektifitas, efisiensi, ekonomis atau tidaknya bidang kegiatan tertentu; (3) Audit Ketaatan (Compliance Audit) merupakan untuk pemeriksaan apakah klien atau nasabah telah mengikuti prosedur atau peraturan tertentu yang telah ditetapkan oleh yang berwenang; (4) Audit $e$ commerce. Bidang audit terhadap e-commerce merupakan kegiatan jasa yang ditekankan pada beberapa hal, yaitu perlunya pengungkapan praktek bisnis, perlunya keyakinan atas keandalan transaksi, dan perlindungan atas informasi; (5) Audit Kecurangan (Fraud Audit). Manajemen fraud menurut Jack C. Roberston, Austin, Texas, mengacu pada kejahatan organisasional, perbuatan para manajer untuk membuat laporan keuangan secara curang, memalsukan, membesar-besarkan atau mengecilkan aktiva atau keuntungan dengan tujuan untuk menipu pihak-pihak di luar organisasi; (6) Audit Sistem Informasi menurut Weber (1999: 10) adalah proses pengumpulan dan evaluasi bukti-bukti untuk menentukan apakah sistem komputer yang digunakan telah dapat melindungi aset milik organisasi, mampu menjaga integritas data, dapat membantu pencapaian tujuan organisasi secara efektif serta menggunakan sumber daya yang dimiliki secara efisien (Gondodiyoto, 2007: 5-45).

Persediaan umumnya mendapat perhatian yang lebih besar dari auditor di dalam auditnya karena berbagai alasan, antara lain umumnya persediaan merupakan komponen aktiva lancar yang jumlahnya cukup material dan merupakan objek manipulasi serta tempat terjadinya kesalahan-kesalahan besar, penentuan besarnya nilai persediaan secara langsung mempengaruhi biaya barang yang dijual (cost of good sales) sehingga berpengaruh pula terhadap perhitungan laba tahun yang bersangkutan, verifikasi kuantitas, kondisi, dan nilai persediaan merupakan tugas yang lebih kompleks dan sulit dibandingkan dengan verifikasi sebagian besar unsur laporan keuangan yang lain, seringkali persediaan disimpan di berbagai tempat sehingga menyulitkan pengawasan dan perhitungan fisiknya serta adanya berbagai macam persediaan menimbulkan kesulitan bagi auditordalam melaksanakan auditnya (Mulyadi, 2001: 135). 


\section{STUDI KASUS}

Sistem informasi persediaan yang sedang berjalan

pada PT SS diawali dengan mengecek stok persediaan,

mengajukan pembelian barang,

menerima barang, mengajukan

pengiiriman barang, meneriman

barang retur, dan membuat

laporan persediaan.

Dokumen sumber pada sistem informasi persediaan

PT SS, yaitu Purchase Order (PO), surat jalan supplier, Bukti

Penerimaan Barang (BPB), Bukti

Penerimaan Barang Retur

(BPB Retur), nota retur, Sales Order (SO), dan surat jalan.

Berikut rencana kerja audit yang akan dilakukan adalah

menentukan ruang lingkup audit sistem informasi persediaan,

persiapan audit lapangan dengan memperkenalkan diri dan

memberitahukan maksud serta tujuan kedatangan kepada

manajer IT dan manajer gudang, dan membuat kuesioner

sesuai dengan ruang lingkup.

\section{DISKUSI}

Saya tidak pernah berdiskusi dengan teman.

\section{E. KESIMPULAN}

Simpulan yang diperoleh berdasarkan tinjauan

dan penerapan tahap audit terhadap pengendalian internal sistem informasi aplikasi persediaan pada PT SS adalah bahwa (1) internal control yang diterapkan di perusahaan sudah baik; (2) management control, application control, dan application software di perusahaan masih ditemukan beberapa kekurangan dan kelemahan yang perlu diperbaiki;

(3) dokumen yang mendukung proses persediaan cukup memadai dan memberikan data informasi yang lengkap dan akurat.

\section{F. REFERENSI}

[1] PUTRA, Arie Setya; FEBRIANI, Ochi Marshella. Knowledge Management Online Application in PDAM Lampung Province. In: Prosiding International conference on Information Technology and Business (ICITB). 2018. P. 181-187.

[2] FEBRIANI, Ochi Marshella; PUTRA, Arie Setya. Sistem Informasi Monitoring Inventori Barang Pada Balai Riset Standardisasi Industri Bandar Lampung. Jurnal Informatika, 2014, 13.1: 90-98

[3] Putra, A. S. (2018, July 9). 2018 Artikel Struktur Data, Audit dan Jaringan Komputer. Retrieved from osf.io/3uq8w

[4]https://www.researchgate.net/public ation/305229484_AUDIT_SISTEM_I NFORMASI_APLIKASI_PERSEDIA AN_PADA_PT_SS 